\title{
PHILOSOPHY
}

UDC 1:94(37)+292

DOI 10.31733/2786-491X-2021-5-17

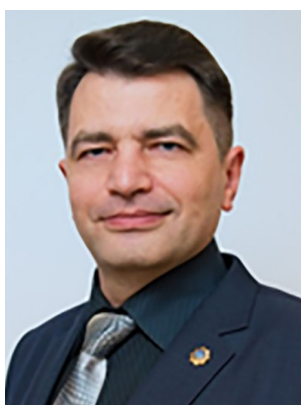

Alex
HALAPSIS
Doctor of Philosophical
Sciences, Professor,
Academician
of the Academy
of Political Sciences
of Ukraine
(Dnipropetrovsk
State University
of Internal Affairs)
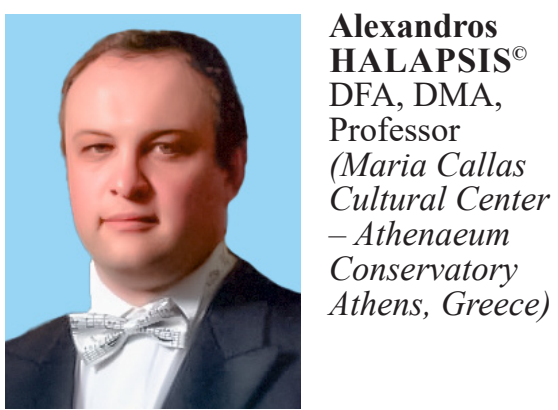

\section{FROM MONARCHY TO REPUBLIC: KING'S POWER AND PUBLIC AFFAIR IN ANCIENT ROME}

Abstract. The exile of King Tarquinius Superbus was surprisingly quick and painless. Although the King was the high priest, the other priests did not seek to challenge his exile, only insisting on the need to save his life. Army commanders did not consider it a treason to move to the side of the rebellious City. The senators, whose mission as elders was to uphold the traditions and way of life of the community, not only did not hinder the revolution, but actually led it. All this indicates that although the exile of the king was an unprecedented event in the history of early Rome, it did not destroy the very model of the universe.

The Republic in Rome was established relatively easy precisely because the idea of a common cause, which meant a collective interest in the prosperity of this new world, was laid down here from the very beginning. The chosen (of the most worthy) kings were to effectively manage the «Roman business», and as long as they coped with it, as long as they ensured the parity of interests of different groups of society, its stable territorial growth and had the support of the gods, no problems arose. Tarquinius Superbus violated an unspoken «social contract» for which he was removed. But this removal did not lead to the cancellation of the contract itself (concluded between humans and gods), and only to its modification.

Getting rid of royal power, which marked a break with the last elements of the traditional world, put on the agenda the question of the need to develop a model that could legitimize the ideal of a common cause. This model is known as «Roman Republic». In its political form, it is opposed to the royal model, but in a worldview, it is a logical development of a Roman idea that has never been associated with either the conception of the divine origin of power or the concept of absolute (and hereditary) monarchy. The continuity between the royal and republican periods of Roman history was expressed in the unity of the original patterns that determine the nature of the Roman idea. Roman society was not formed «for the king» or even «for the gods». The kings and gods served as a means of cementing the community, giving it a sacred nature; the latter, which expressed the concept of the «universal priesthood» as a collective sacred principle, was also the basis of political doctrine. The question of specific forms of government (whether the community will be headed by a lifetime elected king, or magistrates who are elected for a limited time) is secondary.

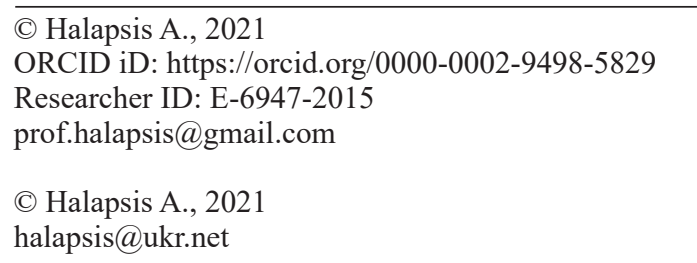


The idea of a collective interest in the success of the common cause was inherent in the Roman project from the very beginning, just a new model allowed it (the project) to be implemented more effectively, facilitating both the coming to power of the most capable members of the community and ensuring the control of the people over the activities of the government.

Keywords: Romulus, Tarquinius Superbus, republic, monarchy, Roman community, king, ancient Rome

Introduction. Ancient Rome. The superstate of antiquity, which grew out of one city, became famous not only for record conquests. Roman law is rightly considered a legal standard, Roman roads have survived their builders for several centuries, the Roman language (Latin) for more than a thousand years after the fall of Rome was used as the main language of science, religion, international communication. Everywhere you look, there are unique achievements, and even if the Romans borrowed something from outside (as they borrowed the idea of law from the Greeks), they gave the borrowing a unique meaning, so there is no place to talk about cultural plagiarism. Apparently, only in art and philosophy the Romans did not surpass their teachers; in all other areas, they either produced the original forms themselves, or developed other people's ideas so creatively that the copies were not worse, or even better than the originals.

But when we talk about Roman civilization, we usually mean its advanced state, when the Roman genius was in the top league of cultural and historical players. The initial period of Roman history - from the founding of the city to the establishment of a republic in it - much less often attracts attention.

The latter is quite understandable, because reliable data on the events of that time are scarce, and what Roman historians say is too similar to a collection of myths and legends. This can be a problem for historians, as they have to solve the very difficult task of discovering the true history of early Rome and separating it from mythological strata, but from a philosophical point of view - as will be shown later - it provides additional opportunities.

Analysis of recent research and publications. The history of early Rome and its most prominent figures is known primarily from the works of Roman and Greek authors such as Titus Livy, Dionysius of Halicarnassus and Plutarch. These stories differ insignificantly, more differences in interpretations of the same events and personalities.

For example, all three of these authors talk about the founding of the city by Romulus and Remus, and there was a fight between the brothers, as a result of which one of the founders died.

As for the further deification of Romulus, their interpretations differ. Although Livy expressed moderate skepticism, he still believed that the actions of the first king were quite compatible with both the belief in his divine origin and his posthumous worship. (Livy, 1967, p. 57). Dionysius expresses doubts for moral reasons, noting that the deity is incapable of an act unworthy of his blessed nature (Dionysius of Halicarnassus, 1960, pp. 473-475). A graduate of the Platonic Academy, Plutarch believed that the complete denial of the divine principle in valor - blasphemy and meanness, and the mixing of earthly and heavenly -stupidity. Man cannot ascend to heaven and become a god; divine bliss can be achieved by her soul, though not immediately. However, the gods may well be involved in human affairs. As for Romulus, Plutarch said: "We should not be incredulous when we see what a poet fortune sometimes is, and when we reflect that the Roman state would not have attained to its present power, had it not been of a divine origin, and one which was attended by great marvels» (Plutarch, 1967, p. 113).

However, no matter how these and later authors of Romulus themselves assessed it, none of them had any doubts about its historicity. And only in the XIX century historians not only criticized the authenticity of some elements of the biography of the first Roman king, but also questioned the very fact of its existence. Yes, Theodore 
Mommsen argued that the whole legend of the founding of Rome belongs to the category of not very witty fiction (Моммзен, 1997, p. 61).

Mommsen's approach became decisive for subsequent historians, most of whom consider Romulus a mythological character. (Cornell, 1995; Momigliano, 1990; Rodríguez-Mayorgas, 2010; Wiseman, 1995). As Mary Byrd noted, it was not Romulus who gave the city its name, but rather its name derived from the name of the city; therefore, Romulus is the archetypal «Mr. Rome» (Beard, 2015, chap. 2 ). However, there are researchers who hold the opposite view, considering Romulus and Remus to be historical figures - the founders of Rome; probably the most famous among them is the Italian archaeologist Andrea Karandini (Carandini, 2011).

Thus, we have before us two versions of early Roman history: chroniclelegendary and scientific-critical. Roman and Greek historians have insisted that Rome was founded by vagrants, vagrants, runaway slaves, adventurers, and other marginals who, led by Romulus, created a city out of thin air. According to Mommzen, the place was not empty, that for a long time there lived communities formed around families, each of which had its own patriarchs, and the city emerged as a result of a long process of unification (sometimes peaceful, sometimes - military) of these families, whose heads became senators, and members - patricians. Accordingly, for the first version the role of the founder was key, for the second - no, because there was no founder in the literal sense. It is likely that the history of Rome was fabricated and Romulus never existed, but we are not researching Roman history, but the Roman idea, so for us the historicity of the first king (as well as the historicity of other figures of early Roman history) is not fundamental. Even if it is irrefutably proven that Romulus is the fruit of a legend, will this information affect our perception of Roman civilization, will it force us to reconsider its contribution to the historical experience of mankind? We do not think so. What matters is not whether she was physically a person with that name and whether she did everything that tradition ascribes to her. An important result, in this case - civilization. And this civilization tied its history and its name to Romulus.

Modern historians question the authenticity of subsequent events in early Roman history up to the exile of Tarquinius; this will be discussed later. But for Roman civilization itself, they were perceived as a reality that was not just a story, but a guide to action and a means of identification. Therefore, it is important for us not so much the circumstances under which the Tarquinius lost his power, but that the future generations of conquerors of the world anderstand the uprising against him as a noble and just cause.

The purpose of our article is to clarify the place of imperial power in the evolution of the meanings of Roman civilization.

Formulation of the main material. Baron Ch. L. Montesquieu (2002) considered one of the reasons for the prosperity of Rome that all its kings were great people (p. 262). Perhaps this is an exaggeration, but if the known images of the first seven Roman rulers at least partially correspond to the personalities of real people, we must admit that the Romans were lucky to have such kings because each of them made a significant contribution not only to community life, but also to development of appropriate worldview strategies; even a negative experience came in handy for the Romans.

There are many examples in history of how a certain action, beginning with great pathos and attracting huge masses of people at first (and even more of them simply dragging them into its orbit) ended quietly and modestly in a short time. Many societies that had high expectations were scattered by the wind of historical changes, many peoples who commanded respect or terrified their neighbors, disappeared. Some cities, radiating power and wealth, turned into building material for some tiny settlement, which surprises travelers with the discrepancy between the former greatness and the current miserable state, and some cities disappeared from the map in the darkness of oblivion waiting for their Heinrich Schliemann. 
Romulus' ambitious project had every chance to collapse, resulting in something quite ordinary, with the death (disappearance) of its charismatic and extremely active author. Romulus actually started a social mechanism from scratch, but he did not set the goal of giving it some spiritual unity. This task was solved by his successor Numa Pompilius (715-673/72 BC), who carried out some administrative reforms, developed a new calendar, and so on; he was the only king during whose reign the Romans were at peace.

But, perhaps, the main merit of Numa Pompilius was to establish a state cult. The significance of this measure is difficult to overestimate, because religion was the only form of ideology that could unite society. Numa was a reformer, not a prophet, he did not invent a new religion and did not leave behind a revelation. He organized and brought into unity the existing Latin, Sabine and other cults, which formed the basis for the further evolution of the Roman religious system. The Roman patriotism in question stems from the awareness of citizens of their sacred duty to protect common altars. We can say that if Romulus created a community, then the second king gave it spiritual integrity.

The third Roman king, Tullus Hostilius, became famous for his military actions, the expansion of Rome's borders, and doubling of its population. Ancus Marcius, the fourth king, made efforts to develop agriculture, handicrafts and trade; in peacefulness he was similar to Numa Pompilius, but at the same time waged successful wars on the neighbors who encroached on the territory of the Roman state. Under the fifth king, Lucius Tarquinius Priscus (Tarquin the Elder), Rome finally became the leader of the Latin League, the Temple of Capitoline Jupiter, the circus, and the sewage system (Cloaca Maxima, which is still partially functioning today) were built.

Servius Tullius, the sixth king, carried out centuriate and monetary reforms, promoted the welfare of society, redeemed the poor from slavery, and so on. He also passed a law that made the plebeians citizens and established other principles of military service; by granting Roman citizenship to the plebeians, Servius Tullius solved the problem not only of the unity of the community, but also of replenishing the army.

Since before Servius only patricians were considered citizens, it is only natural that the people's assembly - the Curiate Assemblies - was a meeting of patricians. Since the plebeians also have now become citizens, it would be natural to allow them to discuss and make political decisions. However, if all citizens have the same political rights, the voice of the most prominent, noble and deserving will inevitably drown in the cries of blacks. At the same time, if plebeians are not granted political rights, it is difficult to demand that they respect laws they have not discussed or passed.

The king resorted to a trick. By endowing all citizens with political rights, he turned these rights into an empty formality by dividing them according to property qualification. All citizens were divided into seven classes, and the first, consisting of those who had one hundred thousand pounds of copper, received 98 votes, and all the other six classes - only 95 votes in total (Gibbon, 2008, p. 19). Thus, every citizen could please his selfishness with the idea of participating in the solution of state issues, but the actual power remained in the hands of the wealthy.

Lucius Tarquinius Superbus, the seventh and last king of Rome, was famous for his successful conquests and extensive construction, and his tyranny and the atrocities of his sons contributed to the Romans' lasting immunity to royal power and the establishment of a republic that would never be formally abolished.

In almost all ancient societies, the supreme power had a sacred nature, because only through correlation with the higher reality did state institutions gain their legitimacy. As is well known, forms of legitimation reflect the prevailing ideological imperatives in society. While in most modern states the legitimation of power is more or less associated with the idea of the expressed will of the people, in most ancient societies it was associated with the idea of the sacred origin of the supreme bearer of 
power and/or his right to a sacred function. In some societies, the ruler was a god, in some - a descendant of the gods, their chosen one, etc.

For the ancient leaders, the right to power was a religious issue, because considered sacred? For example, the Japanese king, who has nominal power and considerable authority in his society, and today is considered by many to be a descendant of the goddess Amaterasu. And this applies not only to polytheistic religions. The first Jewish king, Saul, according to the Bible, was chosen directly by God and anointed by His prophet Samuel.

A similar situation arises with the election of Roman kings, although the selection procedure itself is not entirely clear. As noted by A. M. Smorchkov (2021), «... perhaps it was an informal proclamation of their leader by soldiers, which in Roman practice corresponds to acclamatio (proclamation)» (p. 135). It is even possible that their powers continued every year. The Roman year began on March 1 . On February 23, the Romans celebrated a holiday dedicated to Terminus, the god of the boundaries, and this day was considered the last of the year, and the days from 24 to 28 February were additional (Smorchkov, 2021, p. 124). It was on February 24 that there was a very specific holiday called Regifugium («King's Escape»). The exact meaning of this holiday is unknown, so today there are different interpretations and different parallels with other cultures. Perhaps it was a symbolic act of termination of royal powers with the subsequent reinstatement of the king ${ }^{1}$.

Be that as it may, the king's power was elective, sole (though not absolute) and lifelong (even if not legally, then in fact). Most scholars agree that it was sacred, and the identity of kings was considered sacred by the Romans. Gaining power took place through the inauguration procedure after the prior consent of the gods. Kings were high priests, and their judicial decisions set precedents that had the force of law. The cult of kings continued to operate with the establishment of the republic, and their golden statues were on the Forum until the beginning of the V century. All these facts allegedly clearly indicate the existence of the concept of the divine origin of royal power.

However, the Roman political model of the tsarist period had significant differences from most other ancient societies. Firstly, a hereditary monarchy was not established in Rome, and therefore the divine sanction was not one-time, as in the cases when the founder of the dynasty passed it on to his heirs; here each election of the king required a new sanction. Secondly, the power of the Roman kings was not absolute, because the main decisions concerning the life of the community were made by the senate and the people's assembly (comitia); some historians refer to it as the power of a lifelong magistrate, whose activities were subject to customs and laws (Kofanov, 2001, p. 18). Thirdly, the election of the king by the gods (Jupiter) was not envisaged, but only their approval of the candidate elected by the senate and the people of Rome. Thus, the initiative came from the community, not from the gods, who only had to agree or reject this choice. Fourthly, the priests who ordained the king were not themselves members of a closed caste, but only elected members of the community to whom it trusted to deal with the gods. Fifthly, the Romans treated the gods as patrons of the community, not as its leaders; the task of the kings (as laterthe republican magistrates) was not to fulfill the will of the gods, but only to maintain peace with them (pax deorum). Therefore, I would venture to say that Roman society was built on secular soil from the very beginning, and that royal power was not perceived by citizens as sacred, neither during its operation nor in subsequent epochs.

In general, when it comes to the sacredness of power, and even more so - about its divine origin, it is implicitly supposed the existence of a certain worldview system in which the supreme power is perceived by the subjects as a divine institution, and its bearer - either as a god or as an instrument of higher powers. In any case, it is a

${ }^{1}$ The fact is that the annual cycle had legal significance for the Romans. It was believed that a thing that a person disposes of for more than a year, becomes his own. This holiday could symbolize the fact that although the king managed the affairs of the state, it did not become his «property». 
special figure that is obviously above «all others» due to the special ontological status inherent in him as the «chosen one of the gods». Such vision of supreme power is characteristic of ancient monarchies (among the few exceptions, perhaps, we can name some Greek polises), for European medieval kingdoms, etc. Catholics attribute these qualities (with some reservations) to the pope as the successor of the apostle Peter and the vicar of the Son of God. To what extent were such ideas characteristic of the ancient Romans?

The inauguration ceremony of the kings was clearly religious in nature, and the role of the augurs themselves (hence the name of the ceremony) was to interpret the will of gods, because the Romans needed to make sure of their consent. Romulus was the first to undergo this procedure, which can be seen as a confirmation of the idea of the sacred nature of royal power in ancient Rome, because it was the gods in the person of Jupiter who allowed him to lead the community.

But let us not jump to conclusions. The fact that Romulus became the king is quite natural, because he was the one who initiated the founding of the City, and it was he who was generally recognized leader of the emerging community. It is hard to believe that the passionaries who flocked to him from all over Italy could take his divine patent seriously. Romulus promised (and gave) them opportunities that they would be deprived of while remaining in their usual environment. His popularity is because many people bet on his project, and this bet played out. Even a natural sense of gratitude required special respect for him, as it did later for his memory.

However, the deification of Romulus hardly influenced the attitude of the Romans to the royal power itself, because if they believed that the latter is a necessary element of the divine world order, then immediately after the disappearance of Romulus, the gods would be offered a new king. This did not happen. Throughout the year, the place left by the divine Romulus was vacant. The city was ruled by senators, who divided the royal powers by lot for 5 days (according to other sources - even for one day). Such «five days» could satisfy the ambitions of the City's fathers, many of them were given the opportunity to «be kings», but the apparent ineffectiveness of such short-term governments forced them to abandon this practice. I would like to emphasize that it was not religious reasons that forced them to return to the institution of the monarchy, but quite practical (even technical) considerations.

Romulus himself was not a senator, he stood at the origins of the community and was as if over the process. But after his death (ascension?) the problem of supreme power arose in full growth. Since Romulus left no male descendants (and only a man-warrior could be the leader of the community), it would be logical to expect one of the senators to succeed him. But the senators of the tsarist era are the heads of patrician families. Apart from the «five days» of the interregnum, none of these patriarchs could claim royal power, because if a senator became king, his family would automatically gain an advantage over the others. Therefore, kings were not senators; moreover, they were not even patricians.

The latter circumstance seems impressive only at first glance. Patrician is a member of the family, and if he became king, there would be legal difficulties. It would turn out that as a king, he had supreme power, but at the same time, he would be in full subordination to one of the senators - the head of his family. This would not only lead to the rise of one of the families, but also make very uncertain the status of the senator from whose family the king came. The fact that the senators did not dare to elect a king for a whole year after Romulus' death is explained, it seems to me, not so much by their personal ambitions as by the difficult problem of «where to get a king?». Senators did not fit for such a role, patricians - even more so. Since only patricians were considered citizens of Rome, only non-citizens could be proclaimed kings. That was strange, but there was no other way. The Conscript Fathers were faced with the need to make a difficult decision, and inviting Numa Pompilius, a Sabine ally («so that no one would be offended», according to Livius), was very wise.

The principle of «king-outsider» continued to operate. Ancus Marcius was 
the grandson of the Sabine Numa, both Tarquiniuses came from an Etruscan-Greek family, Servius was a native of the Corniculus destroyed by the Romans. Only Tullus Hostilius, who was the grandson of Hostius Hostilius, a soldier of Romulus, had Roman roots, but the details of the biography of both of these Hostiliuses and their historicity remain in great question.

Romulus at his inauguration, commanded that the community not make anyone king without the consent of the gods. And the Romans did ask for their consent, but at first they decided on the candidate. However, the last two kings - Servius Tullius and Tarquinius Superbus - did not have this formal divine mandate, although only the last of them was perceived as a usurper, and the reasons for this were by no means religious. The reign of Tarquinius Superbus is considered by the tradition as usurpation since his power was not approved by the people; in addition, the last Roman king created a regime of personal tyranny, significantly reduced the senate by the supporters of his predecessor and tried to convene it as rarely as possible. This was one of the reasons for his exile.

It can be concluded that the sacredness of royal power was only secondly associated with divine sanction, and firstly with the choice of the community, which endued the leader with the sacred authority to communicate with the gods. Even if the king did not have a good relationship with Jupiter (as in the case of Tullus Hostilius $^{2}$ ), even if the king «forgot» to ask the gods about his assignment (as Servius Tullius), it did not particularly affect the attitude to the king and his memory, did not abolish the sacred nature of the fact of his recognition by the community, especially if he had merits to it. Thus, already in the tsarist period, a feature characteristic of all Roman history was formed. The sacred nature was inherent not in the bearer of supreme power, nor even in the position he held, but in the community (civitas) and its choice; the deification of kings, as well as later kings, was not the decision of Jupiter and his colleagues, but the realization by the community of its sacred powers.

One of the favorite topics of philosophy of history is the problem of the role of the individual in the historical process. When it comes to a person who changed the course of history, we mean, as a rule, a «great person» - a prominent legislator, reformer, military leader, thinker or prophet. Upon closer examination, it turns out that not only prominent philanthropists of mankind, but also "great villains» are responsible for large-scale changes; however, the difference between the first and the second is often very conditional.

Be that as it may, "great personalities» are opposed to the «masses of the people», and already in such a problematic field a discourse unfolds which is devoted to the degree of historical freedom of the former and the creative possibilities of the latter. But many of the great events that have significantly changed the course of history have nothing to do with the activities of individuals who, for one reason or another, could be called «great». Due to more or less accidental circumstances, individuals who are quite ordinary sometimes play the historical role.

The transition to republican rule in Rome refers to such events. The key figure who caused a chain reaction of only partially controlled events was Lucius Tarquinius Superbus (534-509 BC) - not that ordinary, but not a great person.

The beginning of the reign of Tarquinius Superbus was marked by the assassination of his predecessor, whose plebeian reforms set a patriciate against him and cost him the support of the senate. By the way, Servius Tullius was removed only on the second attempt, because at first Tarquinius' plans were thwarted by the people, who stood up for their beloved king for obvious reasons. Lucius Tarquinius worked on the errors and the next time he dared to take radical action at a time when the people were busy in the fields. He convened a senate and proclaimed himself

${ }^{2}$ Although this ruler had the mandate of the gods, in his fascination with the policy of conquest, he paid little attention to religious ceremonies, for which he was wiped out by the lightning of Jupiter. However, the wrath of the supreme god, having shortened the reign of the third king, did not affect the veneration of those whose merits to the community were obvious. 
king. When Servius appeared before the curia to drive out the imposter, Tarquinius threw him down the stairs to a stone platform, and his supporters killed the monarch.

The senators initially welcomed the change of ruler (they approved him for the post, without a vote in the people's comitia), but the new king did not think to share power with them, surrounding himself with favorites and establishing a regime of unlimited sole power. As a result, Tarquinius Superbus managed to set against him all the segments of people. The last straw for the Romans was the rape of Sextus (one of Tarquinius' sons), the beautiful and virtuous matron Lucretia, the wife of Tarquinius Collatinus, who unable to bear the shame stabbed herself. Outraged citizens, led by relatives of Lucretia, revolted against the king. It was successful. A spontaneous wrath prompted the Romans to close the gates of the city to their king, who was on a military mission at the time, and the army that accompanied him decided to leave their commander-in-chief and side with the people.

Supporters of Tarquinius Superbus tried to organize a royalist coup, but were quickly exposed and demonstratively punished (one of the republican leaders, Lucius Junius Brutus, who had by then become consul, was forced to execute two of his own sons, participants in the uprising). In order to avoid an audit of the republican government, all senators took an oath of allegiance to the people.

When the former king realized that he no longer had enough support in Rome itself, he found nothing better than to turn to his colleagues for help, convincing them that the Romans would try to extend republican forms of government to all of Italy. By instigation of Tarquinius, Lars Porsena (king of the Etruscan city of Clusium) moved his troops to Rome, winning a number of victories and even approaching the City. However, the courage of its defenders embarrassed the foreign monarch. According to legend, the patrician young man Mucius crept into the Porsena's tent with the intention of killing him, but by mistake he took the life of his scribe. When he was captured, he said he was just one of 300 young men who had sworn to kill the occupier leader at the cost of their own lives. To confirm his determination, Mucius reached out his right hand to the fire and held it there until it was charred. This fact impressed Porsena so much that he released the young man (later named Scaevola - left-handed), preferring a peace treaty with the Romans. Tarquinius Superbus himself died in exile in 495 BC. In general, this is how it all ended (Cornell, 1995, pp. 215-217). If we talk about the level of events, this is something like the republic in Rome was established.

Now let us analyze this story.

The reason for the overthrow of the king was Lucretia's rape by Sextus, and some researchers emphasize it, comparing this plot with analogues in the Greek tradition, or considering it as a sacred ritual in which something went wrong, or as an arena of political intrigue, etc. An overview of the relevant reconstructions can be found in the article by Alexander Koptev (2009). Some versions are quite interesting, but it does not seem to me that rituals played a paramount role here. They play the role of ideological support for the system existing in this society and at this moment, but it is hard to believe that they are able to radically change the system itself.

There is also a version that King Lars Porsena (Porsenna) actually captured Rome, forcing Tarquinius Superbus to flee. Porsena, who sought to strengthen his position in Latium, imposed an unfavorable and humiliating treaty on the Romans, and after a while, when the Romans managed to free themselves from the power of a foreign conqueror, and royal power was abolished, they decided to «forget» about this humiliating episode of their history, inventing a plot with both the expulsion of Tarquinius and the heroic struggle against Porsena (Forsythe, 2005, pp. 148-149). This version is also not without interest, but its main disadvantage is that it, like the previous ones, is based more on the conjectures of modern researchers than on historically recorded facts.

But to what extent can the official version expounded by Titus Livius and other ancient authors be considered a «fact?» Concerning the tsarist period of Roman 
history, there is not much information that could rightly be considered established facts. However, the historiographical tradition is in itself a fact of the spiritual life, and this fact reflected a concept that the Romans themselves accepted as truth, recognizing it plausible. The research of historians may force us to reconsider existing reconstructions of empirical facts, but it is unable to influence the facts of spiritual life, which are the interpretation of experience, in this case - the historical one. If generations of Romans believed that Tarquinius Superbus was exiled by outraged citizens, and Porsena was his ally, then even if this was not the case, these newly discovered circumstances will in no way erase from the minds of the Romans what they believed to be true, and most importantly - further actions, which were based on the corresponding picture of the world.

Any political structure has some margin of stability, which determines not only its ability to respond effectively to the challenges of history, but also the inertia of social mechanics. It is important to believe that the establishment of the republic is caused only by the reaction to the willfulness of the king and the adventures of his sons. Even if the personality of Tarquinius Superbus caused such a negative in society that getting rid of his tyranny was perceived as a benefit, the need to expel the king does not imply the need to change the form of government.

Guy Bradley notes that the Roman Revolution was similar to a palace coup, as the overthrow of the regime was led by members of the royal family: Tarquinius Collatin was a cousin of Tarquinius Superbus, and Junius Brutus was his nephew. (Bradley, 2020, p. 132). From the outside, this may seem like something, but palace coups are usually aimed at changing the owner of the palace, not changing the form of ownership of the palace.

But the Roman Revolution was hardly a pre-arranged project. There is no reliable information about anti-royalist societies that would prepare public opinion, conduct propaganda, collect weapons and recruit supporters. If there were any opposition structures, we should not talk about their strength and organization. During the Roman Revolution, many factors were intertwined, which led to the general opinion: the Romans no longer wanted to live the old way. And it was not about replacing the «bad» king with «good», but about a complete reset of power.

In the ancient world there were many examples of uprisings against unpopular kings, cabals against them, coups and even assassinations. Nobody, I think, keeps such statistics, but in any case, this number must be quite significant. As for the cases when dissatisfaction with the monarch led to the abolition of the monarchy, you can count on your fingers. Even long training and favorable conditions did not guarantee the success of the Republicans, because it is much easier to kill a monarch than to destroy the monarchical idea.

In Rome, however, everything happened quickly and almost bloodlessly. It took Titus Livius only a few pages to describe the events starting from the rape and suicide of Lucretia to the exile of the king (Livy, 1967, pp. 201-209). There are no traces of a serious ideological struggle. We can say that in Rome there were not even royalists as such, that is, there were no ideological supporters of the royal power, but a few supporters of Tarquinius himself. Although the king was the high priest, other priests did not try to challenge his exile, only insisting on the need to save his life. Army commanders did not consider it a treason to move to the side of the rebellious City; on the contrary, the army fought desperately against foreigners who tried to regain power to Tarquinius. The senators, whose mission as elders was to uphold the traditions and way of life of the community, not only did not hinder the revolution, but actually led it.

All this indicates that although the exile of the king was an unprecedented event in the history of early Rome, it did not destroy the very model of the universe. Society did not disintegrate or even restructure: patricians remained patricians, plebeians plebeians, and so on. They had to make only the necessary amendments (political, legal and religious) in the form of society functioning. One detail was removed from 
the top, but the pyramid remained standing. Therefore, this detail (I am not talking personally about Lucius Tarquinius Superbus, but about the royal power in Rome in general) was not system-forming, so its elimination did not become a catastrophe for society and did not blow the brains of a completely religious «average Roman» who surprisingly easily adopted the republican paradigm.

But what about the prevailing among historians theory of the sacred nature of royal power in Rome? It seems to me that if for two and a half centuries the Romans were instilled with the idea that the king is a necessary element of the divine universe, that it is his connections with the gods ensure the order and prosperity of the state, that he has a special mandate from Jupiter (Halapsis, 2014), how would they immediately (in a few years) completely change their views? Even when it came to the need to expel the «bad» king, the Romans would immediately fill the vacancy with a «good» candidate (for example, someone like Servius Tullius). If royal power had a sacred (that is, worldview) significance, the Romans would not have abandoned the institution of kings, especially unexpectedly.

Apparently, in their minds this institution did not play such an important religious role with which modern researchers endow it. When kings lost their moral authority, their functions (including sacred ones) were transferred to elected magistrates, and no one saw this as a problem. I have already mentioned that within a year after the disappearance of Romulus (either he was assassinated, which the people accused the patricians of, or ascended to heaven, as the patricians themselves insisted) and the election of Numa Pompilius, the Romans did without kings. The world did not collapse during this year; in fact, this year was the first attempt at republican rule. That is, the idea that the Roman state could cope without kings, did not appear in $509 \mathrm{BC}$, but much earlier.

Thus, the Roman model of the world was never tied with the king, so his exile did not require a radical review of the model itself. The king was neither the vicar of the gods nor their protege. The monarch was the leader of the community to whom it (not Jupiter) gave power, including in the religious sphere. Given that the community chose its own leader itself (and Jupiter only approved him) and endowed him with powers, it is natural that it was able to revoke these powers from a leader who has lost confidence, and generally change the approach to determining its leaders. This seemed obvious, so the exile of Tarquinius Superbus did not provoke religious protests. The absence of ideological struggle between the royalists (monarchists) and the republicans, relatively rapid and painless establishment of the republic confirm the thesis of the secular nature of the institution of royal power in the Roman community. Because the community itself is sacred, it determines those who are entrusted with communicating with the gods on its behalf, as well as the procedure for their appointment.

Conclusions. The Romans saw themselves as a community of equals, managed only by the most worthy, who proved it by their personal qualities, not the antiquity of the family and the right of inheritance. The Republic in Rome was established relatively easy precisely because the idea of a common cause, which meant a collective interest in the prosperity of this new world, was laid down here from the very beginning. The chosen (of the most worthy) kings were to effectively manage the «Roman business» in civil, military and religious aspects and as long as they coped with it, as long as they ensured the parity of interests of different groups of society, its stable territorial growth and had the support of the gods, no problems arose. When doubts about the effectiveness of the royal power arose, it was simply replaced by another form of government, but the principle of community itself (and the idea of a common cause that was at its core) remained intact. Tarquinius Superbus violated an unspoken «social contract» for which he was removed. But this removal did not lead to the cancellation of the contract itself (concluded between humans and gods), and only to its modification.

Getting rid of royal power, which marked a break with the last elements of 
the traditional world, put on the agenda the question of the need to develop a model that could legitimize the ideal of a common cause. This model is known as «Roman Republic»». In its political form, it is opposed to the royal model, but in a worldview, it is a logical development of a Roman idea that has never been associated with either the conception of the divine origin of power or the concept of absolute (and hereditary) monarchy. The continuity between the royal and republican periods of Roman history was expressed in the unity of the original patterns that determine the nature of the Roman idea. Roman society was not formed «for the king» or even «for the gods». The kings and gods served as a means of cementing the community, giving it a sacred nature; the latter, which expressed the concept of the «universal priesthood» as a collective sacred principle, was also the basis of political doctrine. The question of specific forms of government (whether the community will be headed by a lifetime elected king, or magistrates who are elected for a limited time) is secondary. The idea of a collective interest in the success of the common cause was inherent in the Roman project from the very beginning, just a new model allowed it (the project) to be implemented more effectively, facilitating both the coming to power of the most capable members of the community and ensuring the control of the people over the activities of the government.

Although the idea of a common cause, born of awareness of common destiny and common interest, originated in the first settlers, it is somewhat opposed by another trend, which was genetically related to pre-Roman history, and which consisted of the idea of the state as a matter solely «noble». Does the plebs have a relationship with the state, can he influence government decisions, is he part of the community? The second last Roman king gave an affirmative answer to these questions, and it was decisive for the further development of this unique civilizational project. Therefore, it seems to me that the reforms of Servius Tullius, who introduced the plebeians into the Roman community, were much more important to the Roman worldview than the establishment of a republic. After all, forms of government are fleeting, as demonstrated by the following events that historians associate with the imperial era. The power vertical and the methods of its formation are, of course, important, but the worldview issues related to collective identity are much more important.

It is possible (and probable) that the initiators of the establishment of the republic dreamed of a transition from a monarchical to an aristocratic model of power, but these plans (if they existed) were not destined to be fully realized. Since both patricians and plebeians are citizens, the state is a common cause not only of the former, but also of the latter. Of course, class partitioning remained, but it was not impenetrable.

In addition, we must not forget about the evolutionary transformations of the very principle of aristocracy. For medieval Europe, the nobility of origin automatically gave the right to power and privileges, regardless of the identity of the person who claimed this power and privileges. For the Romans (as well as for the Greeks) noble origin was not so much a right as a responsibility. Power in Roman society was not property and could not be inherited. Even royal power was not seen as property; moreover, it was not the property of the empires of the republican magistrates, being legally limited in time. Therefore, the son of the consul could be respected by citizens for the merits of his father, but in itself this did not give him the right to consular post. Imperium was not inherited, the community itself determined the persons worthy of being its (temporary) bearer. And not only representatives of ancient and noble families could be worthy.

The participation of plebeians in the second board of the Decemvirs, their gradual admission to other (ordinary and extraordinary) magistrates (including magistrates of consul and dictator), the abolition of restrictions on marriages between patricians and plebeians, «reconciliation of the gods», etc., testified to the formation of corporate statehood. For the Romans, a republic is not so much a form of political system as a model of society in which every citizen felt like a member of one team. 
Of course, neither the reforms of Servius Tullius nor the establishment of the republic are explained by chance or a simple coincidence. The very idea of a republic is implicitly present in the tsarist period as an inviolable maxim. Roman kings were not autocrats, in their activities they were forced to take into account the views of the community.

The main thing was the community, not the king; when Tarquinius Superbus «forgot» about it, he was quickly «reminded». Implicitly, the idea of a common cause of patricians and plebeians was also present in the minds of citizens before the reforms of Servius Tullius.

The foundations of statehood laid by Romulus and his successors will be used in the future. When the systems of principate and dominate will be formed, these traditions of the Roman Empire will be reproduced, except for one essential difference: the empire was a republican form of government, and therefore the supreme bearer of power was not the ruler but the people of Rome. It is here that one should look for the origins of the Roman idea, which is the ontological project of this original civilization.

Conflict of Interest and other Ethics Statements.

The authors declare no conflict of interest.

\section{References}

Beard, M. (2015). SPQR: A History of Ancient Rome. New York: Liveright. Kindle Edition.

Bradley, G. (2020). Early Rome to 290 BC: The Beginnings of the City and the Rise of the Republic. Edinburgh: Edinburgh University Press.

Carandini, A. (2011). Rome: Day One (S. Sartarelli, Trans.). Princeton: Princeton University Press.

Cornell, T. J. (1995). The Beginnings of Rome: Italy and Rome from the Bronze Age to the Punic Wars (c. 1000-264 BC). London: Routledge.

Dionysius of Halicarnassus. (1960). Roman Antiquities (E. Cary, Trans. Vol. I: Books 1-2). Cambridge, MA: Harvard University Press.

Forsythe, G.A. (2005). Critical History of Early Rome: From Prehistory to the First Punic War. University of California Press.

Gibbon, E. (2008). The decline and fall of the Roman Empire (Vol. 5). TERRA - Book Club. [in Russian].

Halapsis, A.V. (2014). Iovem Imperium, or Sacred Aspects of Roman «Globalization». Scientific cognition: methodology and technology, 33(2), 173-178.

Kofanov, L.L. (2001). The nature of the royal power in Rome VIII-VI centuries. BC. Antiquity and medieval studies, 3. 14-24. [in Russian].

Koptev, A.V. (2009) The Story of the Virtuous Lucretia: Between Literature, Law and Ritual. Antique world and archeology, 13, 176-202. [in Russian].

Livy. (1967). History of Rome (B. O. Foster, Trans. Vol. I: Books 1-2). Cambridge, MA: Harvard University Press.

Momigliano, A. (1990). The Classical Foundations of Modern Historiography. Berkeley: University of California Press.

Montesquieu, Sh.L. (2002). Persian letters. Reflections on the causes of the greatness and fall of the Romans. KANON-press-Ts. [in Russian].

Mommsen, T. (1997). History of Rome. (Vol, 1). Rostov-na-Donu: Fenix. [in Russian].

Plutarch. (1967). Lives (B. Perrin, Trans. Vol. I). Cambridge, MA: Harvard University Press.

Rodríguez-Mayorgas, A. (2010). Romulus, Aeneas and the Cultural Memory of the Roman Republic. Athenaeum, 98(1), 89-109.

Smorchkov, A.M. (2012). Religion and Power in the Roman Republic: Magistrates, Priests, Temples. RGGU. [in Russian].

Wetzler, P. (1998). Hirohito and War: Imperial Tradition and Military Decision Making in Prewar Japan. University of Hawaii Press.

Wiseman, T. P. (1995). Remus: A Roman Myth. Cambridge: Cambridge University Press. 


\section{Олексій Халапсіс, Александрос Халапсіс \\ ВІД МОНАРХІЇ ДО РЕСПУБЛІКИ: ЦАРСЬКА ВЛАДА ТА СПІЛЬНА СПРАВА В СТАРОДАВНЬОМУ РИМІ}

Анотація. Вигнання царя Тарквінія Гордого пройшло напрочуд швидко та безболісно. Хоча цар був верховним жрецем, інші жреці не намагалися оскаржувати його вигнання, лише наполягавши на необхідності збереження його життя. Армійські командири не вважали за зраду перехід на бік повсталого Міста. Сенатори, чия місія як старійшин полягала у підтримці традицій і укладу життя громади, не лише не перешкоджали революції, але й фактично іiі очолили. Все це свідчить про те, що хоча вигнання царя і було безпрецедентним випадком в історії раннього Риму, воно не руйнувало саму модель світобудови.

Республіка так відносно легко встановилася у Римі саме тому, що ідея спільної справи, під якою розумілася колективна зацікавленість у процвітанні цього нового світу, була закладена тут із самого початку. Обрані (з найдостойніших) царі повинні були ефективно керувати «римським бізнесом», і доки вони з цим справлялися, доки вони забезпечували паритет інтересів різних груп суспільства, його стабільний територіальний ріст та мали підтримку богів, проблем не виникало. Коли ж в ефективності царської влади виникли сумніви, іiі просто замінили іншою формою правління, але сам принцип громади (і ідея спільної справи, що була покладена в його основу) залишився недоторканним. Тарквіній Гордий порушив негласний «суспільний договір», за що і був відсторонений. Але це відсторонення не призвело до скасування самого договору (укладеного між людьми і богами), а лише - до його модифікації.

Позбавлення від царської влади, яке знаменувало собою розрив 3 останніми елементами традиційного світу, поставило на порядок денний питання про необхідність розробки моделі, яка могла б легітимізувати ідеал спільної справи. Ця модель відома як «Римська республіка». За характером політичних форм вона протиставляється царській моделі, але в світоглядному плані вона виступає логічним розвитком римської ідеї, яка ніколи не була пов'язана ні з уявленням про божественне походження влади, ні $з$ концепцією абсолютної (та спадкової) монархії. Наступність між царським і республіканськими періодами римської історії виражалася в єдності вихідних патернів, що визначають характер римської ідеї. Римське суспільство сформувалося не «під царя» і навіть не «під богів». Царі i боги служили засобами цементування громади, надання їй сакрального характеру; саме останній, що виражав уявлення про «загальне священство» як колективне сакральне начало, був покладений і в основу політичної доктрини. Питання про конкретні форми управління (чи буде на чолі громади стояти обраний довічно цар, чи магістрати, які обираються на обмежений час) виявляється другорядним. Ідея колективної зацікавленості в успіху спільної справи була властива римському проекту з самого початку, просто нова модель дозволяла йому (проекту) реалізовуватися більш ефективно, сприяючи як приходу до влади найбільш здібних членів громади, так і забезпеченню контролю народу над діяльністю уряду.

Ключові слова: Ромул, Тарквіній Гордий, республіка, монархія, римська громада, ияар, Стародавній Рим.

Submitted: 22.05 .2020

Revised: 14.01 .2021

Accepted: 01.03.2021 